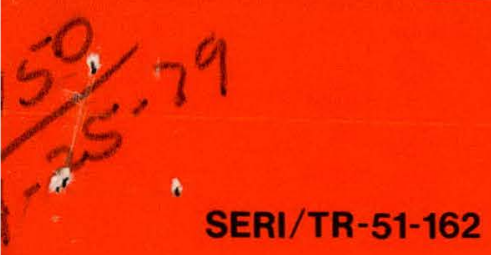

SERI/TR-51-162
March 1979

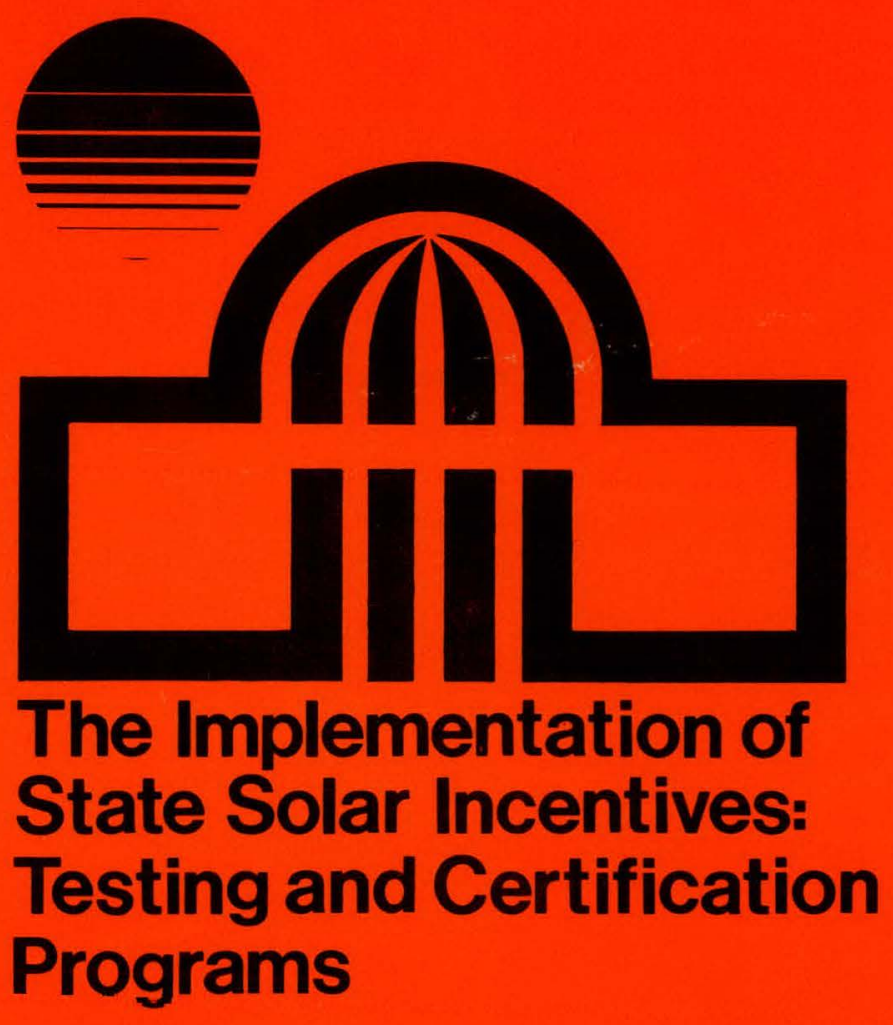

Robert Odland
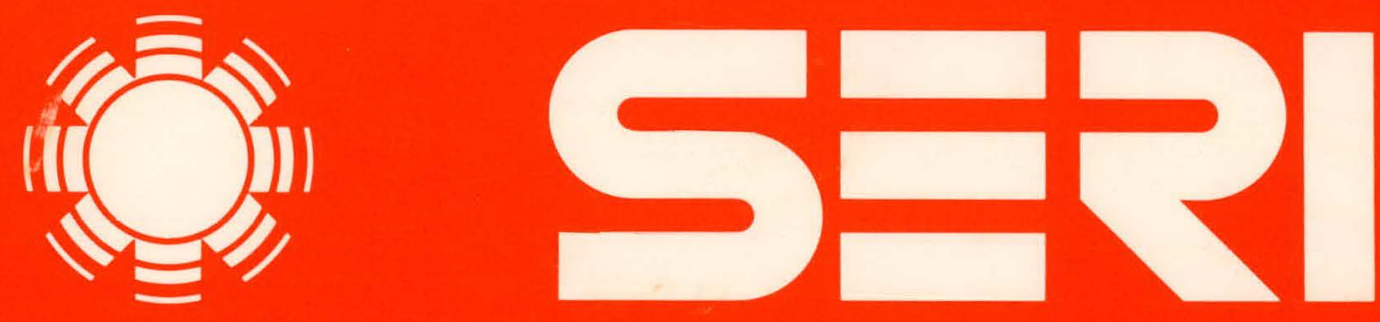

Solar Energy Research Instituto

A Division of Midwest Research Institute

1536 Cole Boulevard

Golden, Colorado 80401

Operated for the

U.S. Department of Energy under Contract No. EG-77-C-01-4042 


\section{DISCLAIMER}

This report was prepared as an account of work sponsored by an agency of the United States Government. Neither the United States Government nor any agency Thereof, nor any of their employees, makes any warranty, express or implied, or assumes any legal liability or responsibility for the accuracy, completeness, or usefulness of any information, apparatus, product, or process disclosed, or represents that its use would not infringe privately owned rights. Reference herein to any specific commercial product, process, or service by trade name, trademark, manufacturer, or otherwise does not necessarily constitute or imply its endorsement, recommendation, or favoring by the United States Government or any agency thereof. The views and opinions of authors expressed herein do not necessarily state or reflect those of the United States Government or any agency thereof. 


\section{DISCLAIMER}

Portions of this document may be illegible in electronic image products. Images are produced from the best available original document. 
Printed in the IInited States of Amcrica Available from:

National Technical Information Service U.S. Department of Commerce

5285 Port Royal Road

Springfleld, VA 22161

Price:

Microfiche $\$ 3.00$

Printed Copy $\$ 4.50$

\section{NOTICE}

This report was prepared as an account of work sponsored by the United States Government. Neither the United States nor the United States Department of Energy, nor any of their employees, nor any of their contractors, subcontractors, or their employees, makes any warranty, express or implied, or assumes any legal liability or responsibility for the accuracy, completeness or usefulness of any information, apparatus, product or process disclosed, or represents that its use would not infringe privately owned rights. 
SER I/TR-51-162

UC CATEGORY: UC-13

THE IMPLEMENTATION OF

STATE SOLAR INCENTIVES:

STATE TESTING AND CERTIFICATION

ROBERT ODLAND

MARCH 1979

\section{Solar Energy Research Institute}

1536 Cole Boulevard

Golden, Colorado 80401

A Division of Midwest Research Institute

Prepared for the U.S. Department of Energy

Contract No. EG $\cdot 77 \cdot \mathrm{C} \cdot 01 \cdot 4042$
This retice

This repon was prepared as an eccount of work sponsored by the United States Govemment. Neither the

United States nor the United States Department of

Energy, not any of theis employees, not any of their

contractors, subconiractors, or theis employees, makes

any warranty, express or implied, or assumes any legal

liability or responsibility for the accuracy, completeness

or usefulness of any information, apparatus, product or

process disclosed, or represents that its use would not infringe privately owned rights. 
TR -162

FOREWORD

This report documents work performed in compliance with Contract No. EG-77-C01-4042, Task No. 5125. The report was prepared by Robert Odland of the Solar Energy Research Institute. This report is a revised part of a larger report entitled "The Implementation of State Solar Incentives: A Preliminary Assessment." The author wishes to acknowledge the extensive research assistance provided by Robert deKeiffer for the preparation of this report and the other reports of this project.

Rabat Collard

Approved for:

SOLAR ENERGY RESEARCH INSTITUTE

Melvin K. Simmons, Assistant Director Analysis and Assessment Division

Robert Odland, Branch Chief Institutional and Environmental Assessment Branch

ii 
TABLE OF CONTENTS

Page

Foreword . . . . . . . . . . . . . . . . . ii

Summary . . . . . . . . . . . . . . . . 1

1.0 Introduction . . . . . . . . . . . . . 3

2.0 Review of Available Testing and Certification

Incentives at the State Level . . . . . . . 5

2.1 Standards .................. 5

2.2 Certification Programs . . . . . . . . . 7

2.3 Potential State Programs . . . . . . . . . 8

3.0 State Testing and Certification Initiatives . . . . . 11

3.1 Florida . . . . . . . . . .... 11

3.2 California . . . . . . . . . . . . . . 12

3.3 Minnesota . . . . . . . ...... 13

3.4 oregon. . . . . . . . . . . . . 14

4.0. Analysis of Testing and Certification Programs

in Selected States............ 17

4.1 Standards ................ 17

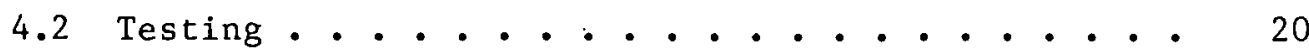

4.3 Certification............. . . 21

4.4 Criteria for State Incentives.......... 24

5.0 Conclusions . . . . . . . . . . . . . . 27

Ceneral Biblïography ................ 31

Appendix A: Standards and Codes . . . . . . . . . 3s

Appendix B: Individuals Interviewed . . . . . . . . 37 


\section{SUMMARY}

Only Florida and California have established conventional-type testing and certification programs for solar collectors. These are programs in which a state acting through an independent testing laboratory certifies that the collector has been tested in accordance with a referenced standard. Other states have established criteria to accompany incentive programs such as state income tax credits. These state statutes may be worded in terms of "certification," but their meaning is that some state agency certifies that the equipment meets the state-established criteria for eligibility for the incenlive.

The two testing and certification programs deal only with flat-plate collectors at the present time. Both Florida and California plan to expand the programs to other components and to some systems in the future. The equipment. covered by the criteria for use with state incentive programs depends upon the language of the statutes; in most cases, active and passive heating and cooling systems are included. In some states, equipment such as windmills is included as well.

The federal government is playing a very active role in standards development, equipment testing, and certification. With the recent passage of federal energy legislation, federal agencies also will be involved in establishing criteria for federal tax credits. The federal involvement plus the activities of many states raises issues of intergovernmental relations. The desire of many states to protect the health, safety, and welfare of their residents may conflict with the desire on the part of the solar industry and others to establish a consistent program to encourage a national market for solar equipment and systems.

The activities of Florida, California, Minnesota, and Oregon are examined. As noted above, Florida and California have testing and certification programs. Both currently are voluntary although certification in Florida will be required after January 1,1980 , and certification in California may be made a condition of their state income tax credit. Minnesota has a system whereby the characteristics of solar equipment are to be disclosed to the buyer; the manufacturer is charged with developing the necessary information. Oregon has several programs which require "qualifying standards" or criteria to be developed. One Oregon program requires "certification" by a state agency.

A major issue with state testing and certification programs is their possible proliferation. A national program, involving the participation of many interest groups, is nearing completion. The costs and the dangers of multiple certification systems should make other states hesitant about developing their own programs. States will continue to have an interest in the eligibility criteria for their tax and other incentive programs. To the extent that these criteria use specific standards, the standards should be consistent with those used by other states.

Design and implementation of state testing and certification programs depend largely upon the uses to which the programs are put. The output of conventional testing and certification programs is test information. There are 
considerable differences in the amount of information and the way it can be made available. Enforcement of legislation and regulations may be an issue in other types of programs.

The "qualifying standards" used for state incentives vary considerably. Some are very general guidelines while others approach the complexity of formal equipment specifications. The use of conventional certification as a condition of a state incentive is expected to increase.

The amount of administrative discretion varies from state to state. A complex and evolving subject such as this may better lend itself to increased administrative discretion because of the technical expertise needed and because of the need to accomodate frequent changes. If this approach is taken, clear policy guidelines are needed in the legislation to avoid legal and administrative problems.

Testing and certification of solar collectors are here to stay and similar programs for other components and solar systems probably will be developed. Testing serves a very important function for manufacturers as well as consumers. Certification provides the mechanism for reporting testing results. State involvement, however, in testing and certification probably will decrease as national programs involving the solar industry become further developed. State involvement in developing criteria used for qualifying equipment for state incentives will parallel the activity in the incentives programs themselves.

Although the study was directed toward the state level, much of the analysis is also applicable to the local level. 


\section{SECTION 1.0}

\section{INTRODUCTION}

This report examines the implementation experiences of several states with testing and certification programs. The primary purpose is to provide information to other states and local governments that are contemplating the adoption and implementation of such programs. A secondary purpose is to provide information to the federal government for their use in formulating national policies which recognize and accommodate regional diversity.

No attempt was made to survey all of the states that have adopted some type of testing and certification program. Only four states were examined; the reasons for their selection are contained in a later subsection. Also, local programs are not included in this analysis. The small number of states and the diversity of the programs make generalizations difficult. Nevertheless, the information contained herein should be helpful to any state or local jurisdiction contemplating action in testing and certification. 
THIS PAGE INTENTIONALLY LEFT BLANK 


\section{SECTION 2.0}

\section{REVIEW OF AVAILABLE TESTING AND CERTIFICATION INCENTIVES AT} THE STATE LEVEL

A certification program consists of a process in which an independent testing laboratory or a governmental agency relying on an independent testing laboratory certifies that a product or a system has been tested in accordance with a referenced standard (one prepared by an organization with recognized authority and credibility). The fact of certification usually is transmitted to the public by means of a label on the equipment. The label may simply state that the equipment has been certified or it may contain specific information derived from the testing process. "Certification" is often used interchangeably. with "listing," although the two have somewhat different technical meanings.

In order to understand state testing and certification programs adequately, the role of standards as well as the role of the federal government in their development need to be considered.

\subsection{STANDARDS}

The basis for a certification program is a set of standards. Standards are an agreed-upon language used by producers, consumers, governmental agencies, and others in communicating the characteristics of materials, products, and systems. Several kinds of standards exist. Ihose relevant to this discussion include definitions, specifications, and methods of test. A standard definition, for example, would differentiate a flat-plate air collector from other types of collectors or even from other types of solar approaches which are not defined as collectors. A standard specification is a set of requirements that must be satisfied by whatever is being tested. A standard method of test covers sampling and describes the testing procedures for determining properties, composition, or performance.

Standards used in certification programs normally are developed in the United States through the voluntary consensus system. The underlying principle in this system is that all who have an interest in the standard should have a voice in its development. This usually includes at least producers, users, consumers, and regulatory agencies. The system works through committees established under the auspices of some private organization interested in developing standards. Examples of such organizations are the American Society for Testing and Materials (ASTM) and the American Society of Heating, Refrigerating, and Air Conditioning Engineers, Inc. (ASHRAE).

Overall coordination of this voluntary consensus system is the responsibility of the American National. Standards Institute (ANSI), whose membership consists of over 400 organizations, many of which write standards. In order for a standard to be referenced as an American National Standard, the procedures of the standards writing organization must be approved by ANSI. Because of the considerable interest in solar technologies, ANSI has established the Solar 
Standard. Steering Committee to oversee solar activities. The committee initially dealt only with standards for solar heating and cooling as well as for solar hot water. The committee's scope has since expanded to include photovoltaics.

Not all standards are developed through the voluntary consensus system. Government agencies may develop standards for their own use in purchasing equipment. Often, however, they use standards developed through the voluntary consensus system. The government also may develop standards to effectuate policies in energy, housing, and urban development. For example, the Federal Housing Administration (FHA) has developed solar standards that have been integrated into their Minimum Property Standards (MPS).

The government, especially the federal government, has become very involved in standards activities related to solar technologies. The primary reasons are to assist in the implementation of governmental policies (noted above) and the push to accelerate the commercialization of solar technologies. Public Law 93-409, the Solar Heating and Cooling Demonstration Act of $1974,{ }^{1}$ called for the development of both interim and definitive "performance criteria" for solar heating and cooling. The National Bureau of Standards has prepared and ANSI has adopted a "Plan for the Development and Implementation of Standards for Solar Heating and Cooling Applications." 2 This plan identifies needed standards and defines priorities, responsible organizations, and schedules. The standards will be developed through the voluntary consensus system.

A good deal of confusion exists between the types of standards discussed above and the standards that are called for in legislation dealing with tax incentives and loan programs. These may or may not be standards in the cunveritional sense; they will be identified as "qualifying standards" in this discussion. Likewise, legislation sometimes calls for equipment to be "certified" by an agency as being eligible for the incentive program. This usually, but not always, means something other than the conventional certification process discussed below.

Another type of standard that adds to the confusion is the standard adopted by a regulatory agency. Examples are water and air-quality standards administered by the Environmental Protection Agency or a state agency. These particular "regulatory standards" deal with the side effects of equipment and systems. Regulatory standards are expected to be particularly important in biomass energy conversion systems.

The discussion in this report primarily addresses solar heating and cooling because most of the activity has been in this area. Increasing interest has been shown in standards and certification. of wood-burning stoves; testing

${ }^{1}$ Solar Heating and Coolịng Demonstration Act of 1974, U.S. Codes Annotated $\S \S 5503-5517$.

2 National Bureau of Standards, Plan for the Development and Implementation of Standards for Solar Heating and Cooling Applications, NBSIR 78-1143A (1978). 
currently is being done by such institutions as the Southern Maine Vocational Technical Institute. Work has commenced on developing standards for windenergy systems and photovoltaic cells. The experience with testing and certification for solar heating and cooling should prove exceedingly useful in developing certification programs for the other solar technologies.

\subsection{CERTIFICATION PROGRAMS}

Certification programs have several general purposes:

- to protect the consumer;

- to assist the industry;

- to protect the value of public subsidies; and

- to contribute to improvements in the state of the art.

These first two purposes are very much related. By protecting the consumer, consumer confidence in solar systems is increased. The increased confidence results in greater consumer acceptance which translates into increased sales. Certification also assists the industry by imposing a consistent set of requirements and by facilitating governmental acceptance of equipment; for example, building officials are much more likely to approve a solar installation if the equipment is certified.

A tension often exists in spite of the close relationship between these general purposes. If standards are not rigorous, business may get a shortterm boost because more equipment will be certified and the cost of production will be kept down. Consumers will benefit from the lower prices but may not be adequately protected. (Note that additional methods, such as warranty programs, also could be used to protect consumers.) More rigorous standards probably mean higher costs of production, higher costs of testing (which is usually paid by the manufacturer), and fewer equipment models being certified. This tension is exacerbated by other standards and certification issues.

- Timing: If the program is established too early in the developmental stages of the technology, it soon will be outdated and probably will discriminate against newer technologies because the mechanism for review and change is so slow.

- Small Businesses: The initial cost of certification may be a hardship for small businesses. Also, small businesses may be producing unique equipment which does not fit into the certification scheme.

- Innovation: The impacts of certification programs on innovation are related to timing issues as well as to the impacts upon small businesses. In addition, the cost and effort involved in testing and certifying improved models of already-certified equipment can discourage product improvement. Also, many independent innovators may be philosophically opposed to participation in a certification program. 
- Passive vs. Active: Certification programs, if not well designed, may discriminate against passive solar systems. This can happen because of ignorance, because passive is difficult to define, or because passive is not oriented toward equipment. Passive systems generally include conventional materials in conventional configurations which do not have significant reliability, durability, and safety problems which cannot be resolved through the local building permit and inspection process.

- Low Cost Alternatives: Certification programs may preclude or discriminate against shorter-life, lower-cost systems that may be as cost effective as longer-1ife, higher-cost systems. Consumer choice must be balanced against consumer protection and potential adverse public reaction due to system failures.

- Kelevance: Existing programs may not be addressing the most significant consumer protection issues. Poor installation and system integration practices as well as unreliable electronic contruls account for a large share of system failures.

- Proliferation: Perhaps the greatest danger of certification programs is that multiple certification requirements will frustrate the emergence of a national solar industry with its alleged economies of scale.

Certification programs normally are established by a private organization. Government involvement, however, has increased in the area of certification of solar equipment and systems. The Solar Heating and Cooling Demonstation Act of $1974^{3}$ addressed certification as well as equipment standards. At the time this report was written, the Solar Energy Research and Education Foundation (SEREF), an organization affiliated with the Solar Energy Industries Association, was under contract with the U.S. Department of Energy (DOE) to design a program for the testing, certification, and labeling of solar collectors. SEREF is not charged with the actual testing or certification. This program will be presented to the ANSI Solar Standards Steering Committee for approval. In addition to SEREF activities, the Air Conditioning and Refrigeration Institute (ARI) has developed a certification program. This program, funded by EKDA through the National Bureau of Standards, was ready for implementation in January 1978. Also, DOE has a program for testing flat-plate collectors.

\subsection{POTENTIAL STATE PROGRAMS}

The timing issue is very critical in discussing potential state responses. Solar standards and certification activities at the national level began relatively recently. The ANSI Solar Standard Steering Committee was established in 1977 and the SEREF certification effort was launched in that same year. The ARI certification program and ASHRAE Standard 93-77, "Methods of

${ }^{3}$ Solar Heating and Cooling Demonstration Act of 1974, U.S. Codes Annotated $\S 5503-5517$. 
Testing to Determine the Thermal Performance of Solar Collectors," also were issued in 1977.

In the past, if a state wanted to have a testing and certification program in effect within its jurisdiction, it had to establish the program. The state could use national standards, if available; if not, or if it felt the national standards were unsuitable for its purposes, the state could develop its own. The state could establish its own testing facility or could accredit private laboratories using standard criteria (if available) or its own criteria. The state had wide options on the content of the label, and it had several options on the use of certification: voluntary, necessary for tax or other incentives, or mandatury for sale of equipment within the state.

In the future, a state could exercise any of the above options. But most important, it could choose to reference or rely upon a national certification program. Assuming that the national program was well conceived and implemented, the state would benefit from not having the significant expense of maintaining a certification program and from the lower cost to its residents for solar equipment as a result of the emergence of a national industry. Also, administrative confusion resulting from different federal and state testing and certification programs would be avoided. 
THIS PAGE INTENTIONALLY LEFT BLANK 
SECTION 3.0

\author{
STATE TESTING AND CERTLFICATION INITIATIVES
}

The state response to the testing and certification issue is related to the level of solar activity within the state. Florida and California, two of the most active states, have developed formal certification programs. Other states have been involved in standards development, usually in conjunction with an incentive program or with some effort to modify the building codes to facilitate solar applications.

This report focuses on Florida and California because of their extensive efforts in this area. Several other states, primarily Minncsota and Oregon, are addressed in less detail. Minnesota was chosen because of the many unique features of the legislation while Oregon was chosen because of the use of "qualifying standards" in multiple incentive programs.

As noted before, states or other levels of government normally are not involved directly in the certification process: the Florida and California programs are exceptions to this general rule. These certification programs involve several types of testing. Some are pass-fail tests (such as stagnation) where the laboratory tests the collector against a standard specification. Others are more like a rating (such as thermal performance) where the laboratory tests the collector in accordance with a standard method of test to produce information on collector characteristics.

\title{
3.1 FLORIDA
}

The Florida program was initiated with the enactment of the Florida Solar Energy Standards Act of 1976.4 This law, effective October 1, 1976, directed the Florida Solar Energy Center (FSEC) to:

- develop standards for solar equipment sold or manufactured in the state;

- establish criteria for determining the performance of solar energy equipment;

- maintain a testing facility for evaluating solar energy equipment performance; and

- allow for the acceptance of test results from other testing organizations.

${ }^{4}$ Florida Statutes Annotated $\$ 377.705$. 
In response to the above legislation, the FSEC prepared FSEC 77-6, "Operation of the Collector Certification Program." 5 This provided the procedure whereby solar collectors are to be rated for performance, examined for compliance to mininum standards, and approved to bear a certification label. A companion document, FSEC 77-5, "Test Methods and Minimum Standards for Solar Collectors," 6 contains the testing and rating methods as well as the equipment specifications.

The program as originally conceived and implemented was voluntary on the part of manufacturers. A recent amendment provides that all solar energy systems manufactured or sold within the state after January 1, 1980, shall meet the standards established by the FSEC and shall display the results of the performance test.

\subsection{CALIFORNIA}

The California program was authorized by legislation adopted in 1977 requiring the California Energy Commission (CEC) to develop regulations governing solar devices. Such regulations could include "standards for testing, inspection, certification, sizing, and installation of solar devices," procedures for the accreditation of laboratories to certify solar devices, prohibition of the sale of solar devices not geeting minimum safety and durability requirements, and several other measures."

The CEC developed the Testing and Inspection Program for Solar Equipment (TIPSE) to implement this legislation. At the present time, the program consists of the following tasks:

$$
\begin{aligned}
& \text { - laboratory accreditation; } 10 \\
& \text { - collector cesting and certification; }
\end{aligned}
$$

${ }^{5}$ Florida Solar Energy Center, "Operation of the Collector Certification Program," FSEC 77-6, November 1977.

${ }^{6}$ Florida Solar Energy Center, "Test Methods and Minimum Standards for Solar Collectors," FSEC 77-5, November 1977.

71978 Florida Laws, Chapter 309; Florida Statutes Annotated $\S 377.705(4)(d)$.

${ }^{8}$ California AB 1512; Statutes of 1977, Chapter 1081.

${ }^{9}$ California Public Kesources Code $\$ 25605$.

${ }^{10}$ California Energy Commission, "Standards and Procedures: Accreditation of Testing Laboratories for Solar Components and Systems," May 31, 1978.

${ }^{11}$ California Energy Commission, "Guidelines for Certification of Solar Energy Equipment," June 15, 1978. 
- information dissemination; and

- syster design and installation guidelines.

The CEC plans to extend its certification program to include a variety of solar devices in addition to collectors--solar tanks, controls, and packaged solar systems. Currently, only flat-plate glazed collectors are being cert1fied.

The regulations incorporated ASHRAE 93-77 as the thermal performance test standard. Because standards for durability, reliability, health, and safety did not exist, the CEC developed their own in consultation with the National Bureau of Standards, the Department of Housing and Urban Development, and the Florida Solar Energy Center. A major difference between the California and the Florida programs is that California does not operate a state testing and certification facility. The impact of this distinction on the industry is minimized by the provision in the Florida statutes that allows private laboratories to test equipment in addition to the FSEC facility. In addition, Florida and California have a reciprocity arrangement dealing with testing and certification.

Currently, the California testing and certification program is voluntary. Within a very short period of tine, the CEC is expected to consider whether certification will be a prerequisite for eligibility for the state $55 \%$ income tax credit incentive. Criteria for the tax credit already have been adopted. 12

In order to provide guidance to consumers on which equipment meets the tax credit criteria, the $\mathrm{CEC}_{3}$ is developing a second program known as the Tax Credit Labeling Program. 13 This program will be administered through the California Solar Energy Industries Association (Cal-SEIA). Cal-SEIA will provide system labels to registered installers. The label indicates to the consumer that the system mects the requirements for the state income tax credit. Both "passive" and "active" systems are included in the labeling program. If the system is installed by a homeowner or a tenant, he or she also can request a label. All participating installers will be required to complete a form describing the type of each installation. These forms are to be returned to Cal-SEIA and would be available to the CEC.

\subsection{MINNESOTA}

Minnesota adopted a provision in 1976 that directed the Building Code Division of the Department of Administration to promulgate rules on the quality and performance standards for solar energy systems. ${ }^{14}$ The standards were to

${ }^{12}$ California Administrative Regulations, $\S \S 2601-2608$.

13 Pierson, Richard, California Energy Commission, conversation with the author, July 10, 1978.

14 Minnesota Statutes Annotated $\S 116 \mathrm{H} .127$. 
insure that the solar energy systems "are effective and represent a high standard of quality of material, workmanship, design, and performance." The standards were to be developed "in consultation" with the Minnesota Energy Agency. They were to be "in reasonable conformance" with the interim performance criteria required under the Federal Solar Heating and Cooling Demonstration Act of 1974. The state standards are to be modified as more definitive standards are developed at the national level.

The use of the standards is that:

"manufacturers or retailers of solar energy systems shall disclose to each bonafide purchaser of a system the extent to which the system meets or exceeds such quality standards."

In response to the legislation, the Building Code Division promulgated rules entitled "Standards of Performance of Splar Energy Systems and Suhsystems Applied to Energy Needs of Buildings." 15 These rules are to be used in conjunction with existing building codes. Enforcement is effectuated by prohibiting any local building official from issuing any permit required for the installation of a solar energy system or subsystem until the seller has provided a disclosure form. The building official is not required to determine the accuracy of the disclosure or to determine if the system or subsystem meets the standards. The standards themselves reference several nationally developed standards as required by the statute.

\subsection{OREGON}

Uregon adopted two statutes in 1977 that involved "certification" of solar equipment. The first, SB 339, established an income tax credit for the installation of an "alternative energy device" which uses solar radiation, wind, nr genthermal energy, ${ }^{16}$ The bill dirocted the Orcgon Department of Energy to adopt rules prescribing minimum performance criteria for alternative energy devices for buildings. In duing so, the department was directed to "take Into consideration" federal performance criteria developed pursuant to the Solar Heating and Cooling Demonstration Act of 1974. The bill provided that the alternative energy device must be "certified" by the oregon Department of Encrgy.

In response to SB 339, the Oreyon Department of Energy promulgated Chapter 330 of its regulations. ${ }^{17}$ The standards for solar equipment are quite general and do not reference national standards except for mention of the ASME Boiler and Pressure Vessel Code. The range of items that qualify as a solar device is

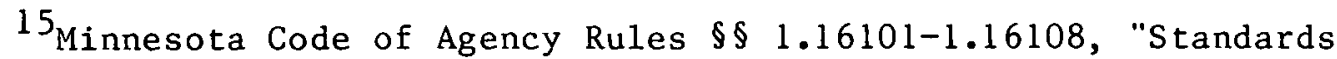
of Performance for Solar Energy Systems and Subsystems Applied to Energy Needs of Buildings," 1977.

${ }^{16}$ Oregon SB 339, 1977; Oregon Revised Statutes $\$ \$ 469.160-469.180$.

17 Oregon Administrative Rules $\S \S 330-80-010$ - 330-80-080. 
broad. The regulations contain an exemption from the standards for "innovative and creative projects" and especially encourage home-built systems.

The other piece of legislation in 1977, SB 477, permitted eligible veterans to obtain up to an additional $\$ 3,000$ as a loan from the Oregon War Veterans' Fund. 18 This bill uses virtually the same definition of "alternative energy device" as SB 339. SB 477 required the Director of Veterans' Affairs, with the advice and assistance of the Oregon Department of Energy, to adopt rules prescribing minimum performance criteria for the alternative energy devices. The Bill also provided that the Director of Veterans Affairs could contract with the Oregon Department of Energy for certification of the devices which complied with the performance criteria.

The performance criteria adopted by the Department of Veterans' Affairs read as follows: ${ }^{19}$

- Alternative energy devices must supply at least $10 \%$ of the total energy requirements for a home.

- Minimum expected operating life of alternative energy systems must be at least ten years.

- Alternative energy devices must be installed in a location and in a manner that will optimize their operation.

The Department of Veterans' Affairs has not contracted with the Oregon Department of Energy for certification of alternative energy devices.

Another bill was passed earlier (1975) to grant a property tax exemption for solar energy equipment. 20 No provisions were made in the legislation for standards or certification. Most tax assessors are using the income tax credit criteria to determine if the solar equipment is eligible for the property tax exemption. ${ }^{2}$ The Department of Revenue is expected to ask the legislature for statutory guidance on qualifying standards during its next session.

${ }^{18}$ Oregon SB 477, 1977 ; Uregon Rev1sed Statutes $\$ 407.048$.

${ }^{19}$ Oregon Administrative Rules $\$ 274-20-345$.

${ }^{20}$ Oregon HB 2202, 1975 ; Oregon Revised Statutes $\$ 307.175$.

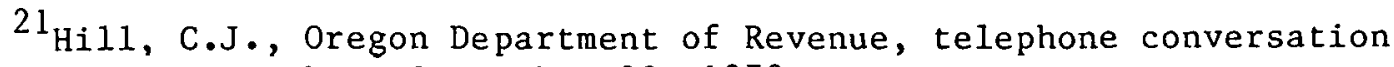
with the author, September 22, 1978. 
THIS PAGE INTENTIONALLY LEFT BLANK 


\section{SECTION 4.0 \\ ANALYSIS OF TESTING AND CERTIFICATION PROGRAMS IN SELECTED STATES}

The analysis of state testing and certification programs is divided into four sections:

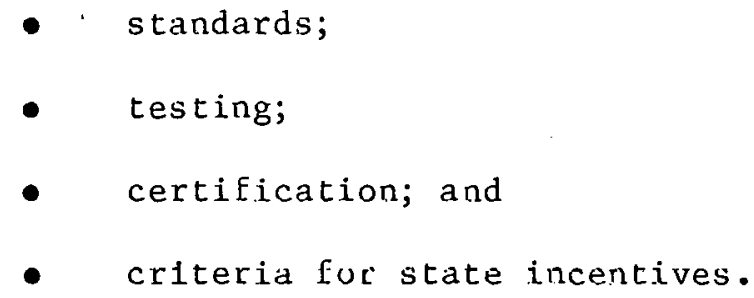

This analysis will provide information useful to states (and local governments) considering the adoption of a testing and certification program.

\subsection{STANDARDS}

This subsection discusses standards which are developed primarily for the purpose of quality assurance. Although these standards nay be used in state or local incentive programs, this use is secondary. "Qualifying standards" or criteria are addressed later.

The state with lead involvement in equipment standards development is Florida. Other states such as California and Minnesota have used standards developed by others as their starting point. Florida became involved because needed standards were lacking at the time its testing programs were being developed.

A state's response to solar standards setting should be tailored to the use it expects to make of standards. Possible uses include:

- prohibiting manufacturing within the state of equipment not meeting prescribed standards;

- prohibiting sale within the state of equipment not meeting prescribed standards;

- purchasing only equipment which meets the prescribed standards;

- offering tax and other incentives only to equipment which meets the standards;

- incorporating standards into building codes; and

- making information available on equipment meeting the standards. 
As noted before, equipment standards normally are not developed by states. Several reasons exist:

- the process is expensive;

- if standards already exist, the process may be duplicative;

- state standards may be of poorer quality than national standards because of. limited involvement and perspective of interest groups;

- industry may ignore the standards;

- standards development may be untimely; and

- problems associated with proliferation will increase.

The proliferation issue is perceived by the solar industry to be of extreme importance. Businesses operating in several states feel that they cannot operate effectively if they must meet multiple standards. Businesses operating entirely within a state may find that they are not able to expand to other states with different standards or that they cannot take advantage of federal. prograns within their state which use national standards. One firm which recently shut down its solar branch stated: ${ }^{22}$

Multiple and conflicting product performance criteria and warranty requirements are either being imposed or recommended by just about every local, state and federal goveranent agency, industry assoriation, trade association and so forth. This makes it virtually impossible for manufacturers to forecast the ground rules and eventual economic outone of their solar program.

A major challenge for ail levels of govermilent is to develop a system for s,tandards (and testing and certification) which addresses the concerns of the industry but at the same time preserves flexibility at the state and local level for unique, innovative, and low-cost solar systems. The system also. must protect the health, safety, and welfare of the public.

The first question a state needs to answer, given the problems of developing standards and their potential uses, is whether any activity is needed at the state level. National standards have been or are being developed for solar heating and cooling systems, subsystems, components, and materials. A state may be concerned about several potential problems with the national standards including:

${ }^{22}$ Burke Industries, San Jose, California, as quoted in editorial in Solar Engineering, p. 5, May 1978. 
- the accommodation of regional variations; and

- the accommodation of equipment not meeting national standards.

The regional variations include special problems of high or low temperatures and solar radiation levels, high winds, blowing sand, snow loading, or hail. The recommended approach appears to be to work with existing standards development groups to accommodate those regional variations. A well-designed standard should do this. This would enable a state to choose standards applicable to its regional needs if it determined that the national standards were not appropriate.

A state may wish to reject for use a standard that is preventing or inhibiting the sale of equipment which it feels should be allowed to compete. Or, as will be discussed later, a state may adopt a standard but provide variances for innovative equipment. Standards should not preclude the construction and use of home-built solar systems, although criteria may be appropriate to determine if they qualify for government incentives.

Care must be taken in drafting legislation to define what is covered. For example, the recent amendments to the Florida standards statutes appear to require that all solar systems sold after a certain date must meet the prescribed standards. ${ }^{3}$ This appears to cover used solar systems, installed before the effective date and sold later separately or as part of the building, as well as home-built solar systems that are later sold. It is doubtful that this was the intent of the legislation.

Standards have not yet been developed for many of the other solar energy technologies although they may exist for certain components of those systems. (Systems standards may not be feasible for some technologies because of the variations in components and variations in applications.) Rather than have the states become involved in the development of standards for other technologies, their most sensible approach appears to be to maintain a hands-off position except for making their concerns known to DOE and the standardswriting bodies and providing participants in the process.

Standards were developed in Florida and California by a governmental agency which dealt with energy and in Minnesota by the agency which administers building codes. No conclusion can be drawn as to the effectiveness of one approach over another in terms of the quality of the standards that were developed. However, there is a significant difference in the implementation of the standards. Part of this may be the product of the organizational structure, but a larger part probably results from the use of the standards themselves.

Florida and California use their standards in their testing and certification prograins. Minnesota uses their standards in a disclosure program administered by local building officials. This program requires that the manufacturer or retailer disclose the extent to which the solar systems meets state adopted

23 Florida Statutes Annotated $\$ 377.705(4)(d)$. 
standards. There are some indications that the Minnesota program is not working effectively. The disclosure statements may or may not be accurate; one reason for this is that many manufacturers do not have good information on their products. Information on home-built systems usually is nonexistent. Building inspectors are often more concerned with obtaining a form than in its substance. Buyers may not be seeing the forms. Furthermore, the information on the form is not checked on a systematic basis. There are likely to be several reasons for these problems:

- The state energy agency has no role in implementation.

- The statute, under the best of conditions, appears to lack any effective enforcement mechanism.

- A mechanism to provide equipment testing is lacking.

- A better education program for building inspectors is needed.

- A better public information program is needed.

Another issue is whether the "purchaser" of solar systems installed on a house is the builder or the subsequent owner/occupant of the home. This should be clarified.

In defense of the Minnesota system, the implementation phase is very new. There is no reason to expect that the existing problems will not be corrected. An interesting issue, however, is raised. A state can implement a system and work out the problems as they develop. Alternatively, it can delay the effective date to give it time to address in advance the problems that can be expected to occur.

\subsection{TESTING}

A state would normally become involved in testing for one or both of the following reasons:

- as a necessary component of a certification program; and/or

- to provide feedback to manufacturers.

Certification in the conventional sense requires testing; this factor differentiates the certification programs in Florida and California from those of other states.

The function of providing feedback to manufacturers is very important. Manufacturers, especially smaller ones, usually do not have adequate test facilities. Therefore, they often do not know how their collectors perform under a variety of conditions. Manufacturers can use the test results to correct deficiencies and improve performance. Manufacturers also can use the test results to compare their equipment with that of other manufacturers. 
Florida and California have taken different organizational approaches to testing. Florida operates a test center, while California accredits laboratories to do its testing. Florida set up its own facility to work directly with the solar industries within the state. Also, at that time, not many private laboratories were in the business of testing solar collectors. California rejected the establishment of a state laboratory because of the expense and because private laboratories were available.

One advantage of the Florida laboratory is the lower cost to the manufacturer of testing. The current fee for testing and certification of a flat-plate collector is $\$ 1350$. The prices for private laboratories vary, but are generally $\$ 400$ to $\$ 500$ more. Information on the cost to the laboratory of testing collectors was not obtained. If, as some people in private industry allege, Florida's costs are more than the fee charged, the difference is a subsidy to manufacturers who choose to have their collectors tested in the Florida laboratory.

A question which could be asked but which was not analyzed was whether a state laboratory provides better feedback to manufacturers. Because the laboratory, under the Florida Solar Energy Center, has an institutional interest in solar energy, it may be more willing than private laboratories to work with manufacturers in product improvement. No research was conducted to see if this is true. On the other hand, one could argue that having testing laboratories work closely with manufacturers may present a conflict of interest. Also, laboratories may help one manufacturer by recommending a solution learned from testing a collector from another manufacturer. Some manufacturers may not be willing to tolerate such an exchange of technical information.

Another difference between the two programs is the emphasis that California places on the inspection of solar equipment specifications, design, and drawings after testing is completed. This inspection by engineers at the Energy Commission provides information, especially on durability and reliability, not obtained during the testing process. Plans call for this information to be used in two ways. The inspection results will be given directly to the manufacturer who can use them for product improvements. Also, selected information will be presented in a common format in brochures and distributed to consumers and manufacturers so that meaningful equipment comparisons can be made.

\subsection{CERTIFICATION}

As noted earlier, certification consists of having an independent testing laboratory or a government agency relying on an independent testing laboratory certify that a product or a system has been tested in accordance to a referenced standard. Standards and testing were discussed in the preceding sections. The purposes of certification are consumer protection and aid to the industry through greater consumer confidence and institutional acceptance of the equipment. The latter includes the greater acceptance by building officials and lenders, lists of equipment approved for governmental purchasing, and equipment made eligible for governmental incentives. 
Certification of solar collectors currently is being carried out by a very limited number of testing laboratories using test procedures adopted by California and Florida. As mentioned earlier, the Solar Energy Research and Education Foundation is developing procedures for a national certification program. Certification will be conducted by laboratories which are accredited using criteria currently being developed.

The certification programs of California and Florida are very active. As of October 1978, about 66 manufacturers with 190 models were participating in the first round of testing and certification in the California program. ${ }^{24}$ This testing was being conducted in six laboratories. Both Florida and California worked closely with industry in establishing the programs. Meetings and public hearings were held during the development and adoption of the regulations and guidelines. Meetings were then held with manufarturers to assist them in applying for certification.

California was assisted by a consulting firm in establishing a certification program. 'lhe firm proposed criteria for laboratory accreditation, assisted in the accrediting review process, and developed the form of the documentation required from manufacturers. The laboratory accreditation process is very complex, a fact that may deter other states from undertaking it.

A major component of certification is the communication of the technical information obtained during the testing process. The amount of information that can be developed and displayed is limited by the size of the label. The Florida label is consumer oriented--it provides the thermal performance rating based on an "assumed standard day" for Florida and also provideo the collector area. The California label, on the other hand, will also have information of use to installers and maintenance people. 25 As noted earlier, there are plans to augment the label with a more detailed information brochure.

Florida has a consumer data sheet which sellers hand out to prospective buyers. This sheet gives more information than is on the label. In addition, a complete test report on any collector is available from the Florida solar Energy Center. The availability of the data sheet and the test report are noted on the collector label. Another aspect of documentation requirements is the material necessary to integrate the components into a system. California requires this information before a collector can be certified.

A complete documentation program should address these nepds:

- consumer information on safety, performance, etc.;

\footnotetext{
24 Reyneveld, Josh, California Energy Commission, telephone conversation with the author, October 5, 1978.

${ }^{25}$ California Energy Commission, "Guideline for Certification of Solar Energy Equipment," June 15, 1978.
} 
- information for solar system designers;

- information for installers;

- information for repair persons; and

- detailed technical information.

Consumer information, in particular, needs more study. Information must be useful but not too technical. Also, attention must be paid to making the certification information usable to the people who prepare and administer building codes.

As noted earlier, certification programs may be used in a number of ways. They can be voluntary as in California or as in Florida until January 1, 1980; they can be required for a tax-incentives program (discussed in the next subsection); or they can be mandatory as in Florida after January 1, 1980. Manufacturers have a great incentive to participate in certification programs even if they are not mandatory. Experience in Florida indicates that manufacturers use the fact of certification as a selling point; an informed consumer soon learns to ask if a system or component is certified. ${ }^{26}$ Similarly, if a state requires certification for tax or loan incentives, participation in the certification program will be necessary for commercial success.

Certification may be a financial burden for small businesses. The current cost of testing and certifying one model of a collector, including documentation, may be over $\$ 2000$. This cost is probably reasonable because of the value of the feedback to the manufacturer and the increased salability of the product. However, if the manufacturer does not have the necessary money, such benefits cannot be realized. An approach to solve this problem was attempted in California. A program was developed for state subsidies for small solar businesses to enable them to participate in the certification program. The subsidy program died in the economy wave that recently swept the state. Note, however, that such a program does not add up to very much total expense to a state.

Another potential problem with certification is that product improvements, common in the early stages of industry, may require retesting and recertification. Some discretion to accommodate product improvements should be built into the certification programs. Someone should have the authority to say that the change is so minor that new testing is not required or that only some tests are required. Another approach, being developed in California, is to use a computer model to predict how a change in one part of a collector will affect its overall charactcriotico.

The use of a certification program may determine the method of adoption of the guidelines. California developed guidelines, but as of October 1978, has not adopted the guidelines as formal regulations. The reason is twofold. First,

${ }^{26}$ Roland, James, F1nrida Snlar Energy Center, conversation with Bruce Green (SERI), September 21, 1978. 
the certification program was voluntary which caused the state to determine that regulations were not required. Second, and more important, the Energy Commission felt that the lack of experience with the criteria meant that it was premature to adopt them as formal regulations. 27 A decision was made to gain experience with the criteria before they were adopted as regulations. This decision coincided with a decision to delay making certification a requirement for the tax credit. This "phasing" approach to regulation makes sense for subjects such as solar that are new and involve a substantial expenditure of funds for some businesses.

\subsection{CRITERIA FOR STATE INCENTIVES}

Almost all state statutes establishing an incentive program make some reference to what equipment qualifies for such incentives (exceptions will be noted later)." The legislation itself may provide detailed criteria, it may call for some agency to establish criteria, or it may call for some agency to "certify" the equipment as being eligible. The two meanings of certification must be kept clear.

The Oregon legislation that established the state solar tax credit required the Oregon Department of Energy to certify equipment before it was eligible for the tax credit. ${ }^{28}$ The Department can take the definitions from the statute, adopt amplifying regulations, and then determine if the equipment meets the state criteria. If it does, the equipment is certified. Similar California legislation required the Energy Commission to establish guidelines and criteria for eligible systems. ${ }^{29}$ The Commission did so in a set of regulations entitled "Tax Credit Guidelines and Criteria." 30 Other legislation called for the development of solar standards and led to the development of the certification program. ${ }^{31}$ Certification here means testing by an independent laboratory in accordance with a reference standard. Certification is not required for the tax credit but it may be in the future.

27 Wheatland, Gregg, California Energy Commission, conversation with the author, July 11, 1978.

*A related concept is represented by the unique ordinance recently enacted by San Diego County, California (Ordinance No. 5324, December 12, 1978). This ordinance requires the installation of solar hot water systems in new residential construction. It states that the county will consider an additional ordinance "to make provision for solar system materials and installation standards" and will consider whether to require state-certified systems to be used.

28 Oregon Revised Statutes $\$ 469.170$.

${ }^{29}$ California Revenue and Taxation Code $\$ \S 17052.5$ and 23601 .

${ }^{30}$ See note 12 .

${ }^{31}$ California Public Resources Code $\$ 25605$. 
A good deal of discretion to the administrative body is granted by the California and Oregon legislation. The Oregon tax credit legislation provides: 32
"Alternative energy devices" means any system, mechanism or series of mechanisms which uses solar radiation, wind or geothermal resource as a source for space heating, water heating, cooling, electrical energy or any combination thereof for a dwelling which source meets or exceeds $10 \%$ of the total energy requirements for the dwelling.

The regulations resulting from the legislation include the following solar devices:

- solar collectors;

- movable insulation;

- Trombe walls;

- attached solariums;

- thermal mass;

- solar assisted heat pumps;

- ductwork, controls, etc.; and

- south facing windows (neeting certain conditions).

The California legislation 33 used the term "solar energy system" which was defined as equipment (a) "which uses solar energy to heat or cool or produce electricity;" and (b) "which has a useful life of at least thrce ycars." The implementing regulations included a variety of active and passive systems as well as systems for swimming pools and hot tubs. The regulations also were written to include warranty requirements and mandatory conservation measures. In addition, both sets of regulations provided for administrative discretion to exempt unique systems from meeting the specific criteria. An applicant can request such exemptions and it may be granted by the administrative agency. Also, both states have provisions for including solar systerns not specifically listed in the regulations.

In some situations, incentive legislation may include no provisions for criteria. An example is the Oregon property tax exemption for solar energy equipment which is silent on which equipment qualifies and does not direct the development of criteria. ${ }^{34}$ Legislation recently adopted in California

${ }^{32}$ Oregon Revised Statutes $\$ 469.160$.

${ }^{33}$ California Revenue and Taxation Code $\$ 17052.5$.

${ }^{34}$ Oregon Revised Statutes $\$ 307.175$. 
providing for soląr loans simply directs the California Energy Commission to develop criteria. ${ }^{35}$ In some states, these examples might be an excessive delegation of legislative authority. Also, questions can be raised to whether it is good policy to leave so much discretion in administrative agencies.

The detail of implementing regulations can vary considerably. The regulatory provisions for the Oregon tax credit are 15 pages long, while the regulations for the Oregon veterans' loan program consist of three short statenents. Both programs use virtually the same statutory definitions of "alternative energy device."

The existence of the two sets of regulations in Oregon raises other interesting issues. Why have two sets of criteria and what are the effects of so doing? The purpose of the Oregon veterans' loan program is to provide loans to eligible veterans. The program is oriented to providing a service to as many veterans as can quality. Also, for all practical purposes, it is financially independent from the rest of state government. The criteria are very general. The tax credit program, on the other hand, tries to balance promntIng solar applications, encouraging good quality systems, and protecting the state treasury. Therefore, its regulations are more detailed. This dual system seems not to have caused problems in practice although it may be too early to make a definitive judgment. ${ }^{36}$ People participating in both programs normally go to an office of the Department of Veterans' Affairs first where they are told about the tax credit program and that its criteria are different from the loan criteria.

In the future, states establishing "qualifying standards" for state incentives will need to consider the criteria for the federal income tax credit. States may wish to use the federal criteria (not adopted at this time). Good reasons may exist for deviations, such as when the federal provisions do not apply to a type of system the state has determined to be useful. Tf differences are to exist, they should be carefully spelled out to avoid confusion to the consumer.

In establishing criteria for incentive programs, sufficient time must be allotted for manufacturers to comply with the regulations. For example, in California the guidelines and criteria for the tax credit have been implemented while a decision as to whether certification is required for the tax credit has been postponed. One of the reasons for delaying the certification requirement is that manufacturers would not have had time to comply; when equipment begins to become certified, a decision presumably will be made on making it a condition of tax credit eligibility.

Criteria for state incentives probably always should be adopted as formal regulations. California again provides a good example. Although the certification program has not been adopted as formal regulations, the tax credit guidelines and criteria have been. One reason for doing this is to provide more certainty to the taxpayer because regulations generally are considered

${ }^{35}$ California Health and Safety Code $\$ 41261$.

${ }^{36}$ Clark, Norm, Oregon Department of Veterans' Affairs, conversation with the author, July $12,1978$. 
more difficult to change. ${ }^{37}$ This difficulty, however, may be a disadvantage as implementation problems are discovered.

Linking certification to state incentives appears to be an effective way of protecting the consumer and also protecting the state treasury. If this link is made, the program should do the following:

- provide for home-built systems;

- provide for systems, such as passive, which are not certified in the conventional sense;

- provide for innovative and alternative approaches; and

- provide for the resale of equipment initially sold before the certification requirement.

The California Tax Credit Labeling Program, described earlier, is unique in that it provides assurance to a consumer that the system meets the adopted guidelines and criteria; it has no connection with the certification program. The program is administered by the California Solar Energy Industry Association and the labels (bearing the name of The State of California) are applied by the installers. The program also is unique at the state level because no enabling legislation exists and because the concept originated largely from the private sector. Several concerns have been voiced on the proposed system:

- tax credit labeling may be confused with equipment certification;

- considerable authority is being delegated to a private association; this includes placing a "State of California" label on solar systems;

- consumers may interpret the label as a state guarantee;

- labeling of passive systems will be especially difficult to monitor; and

- the Energy Commission may be liable if subsequent monitoring shows that the system does not meet eligibility requirements.

The program, if implemented, will be voluntary--a label will not be required to receive the tax credit.

The Tax Credit Labeling Prngram will be very useful in providing information for the analysis of the tax incentive program. A form must be submitted on every installation provided with a label. This information can be used by both the industry and the state in analyzing the specific types and locations of installations.

37 Wheatland, Gregg, California Energy Commission, conversation with the author, July $11,19 \%$. 
THIS PAGE INTENTIONALLY LEFT BLANK 
SECTION 5.0

\section{CONCLUSIONS}

Initiation of Programs. States should begin to develop solar equipment standards and testing and certification prograns only after exploring other alternatives. If the primary purpose is to provide quality assurance of solar equipment, the national prograns being developed should satisfy this requirement. If they do not, the best approach appears to be to work with the organizations establishing the national programs. A good national prograul should produce standards suitable for all regions. If this approach is not satisfactory, and the state still feels a need for additional or different standards, such standards development should be tied in as closely as possible with national standards aud should provide a mechanism for converting to a national standard should one be adopted. Another approach that may be useful is to adopt a national standard while providing an alternative path for equipment that is very new or innovative.

Focus on objectives. The first step in implementing a testing and certification progran is to determine its objectives. The type of progran that is developed as well as the techniques of implementation should then be tailored to these objectives.

Evaluation. Evaluation should be built into any testing and certification program. This is needed to determine if the progran is meeting its stated objectives and to determine what impacts the progran is having on such issues as equipment costs, introduction of new equipment models, and burdens upon sinall businesses.

Implementation Addressed in Legislation. The legislation should specify how the testing and certification program will be implemented. Any progran worth adopting should be worth being made to work. The legislation should provide Eor implementation flexibility.

Comprehensive Approach. The implementation proyram should be comprehensive. This includes education, assurance of adequate equipment data, and an enforcement mechanism. Education should extend to the industry, the general public, and state and local (if used) administrators. If a progran requires the communication of information about equipment, sone type of testing provisions must be rade to provide this information. Hnforcement is necessary to provide consumer confidence in the products.

Administrative Discretion. Broad administrative discretion may be suitable in this area because of the technical nature of the subject and the need to revise the rules because of rapid advancements. Proper exercise of administrative discretion requires clear policy guldelines in the legislation.

Benefits of Testing. The testing of solar equipment is necessary for the advancement of the technology. Testing provides information used by manufacturers to improve their equipment as well as information to consumers 
and others who nust install, use, or maintain the equipment. Many manufacturers, especially stnaller ones, do not have the capability to do this testing.

Information Dissemination. The information obtained frorn testing and certification prograns is very important. This information should be available in a variety of forms for different users. In addition to consumers and manufacturers, these include designers, installers, building inspectors, lenders, and malntenance personnel. The information should be useful to people in different geographical areas.

Criteria for Incentive Programs. The equipinent "qualifying standards" for state incentive prograins should be coordinated with the criteria for the federal income tax credit and with criteria used by other states. Flexibility should be provided to cover home-built, unique, and innovative applications.

Flexibility in Certification. If formal certificatlon is nade mandatory or made a condition for an incentive progran, the legislation should provide for home-bulit systems, for approaches sucis as passive heating and cooling that are not oriented toward using specific equipment components, for innovative approaches, and for the resale of equipment originally sold before the certification requirement.

Advocacy vs. Regulation. The dangers of conflicting agency responsibilities must be recognized. A state energy office usually plays an advocacy role for solar energy. This role may conflict with its regulatory functions such as assuring equipment performance, reliability, and durability. If a single agency is to do both, its internal procedures should recognize the potential conflict and provide a mechanism for dealing with it. 


\section{GENERAL BIBLIOGRAPHY}

AIA Research Corporation, Early Use of Solar Energy in Buildings, A Study of Barriers and Incentives to the Widespread Use of Solar Heating and Cooling systems, Washington, D.C.: AIA Research Corporation for NSF, Washington, D.C. August 1976.

American National Standards Institute, American National Standards Institute Procedures for Managenent and Coordination of American National Standards, New York, 1974 .

American National Standards Institute, How American Standards Are Made, New York, New York, 1960.

Anerican Society for Testing and Materials, Standardization Basics, Philadelphia, Pennsylvania 1974.

ARI, Standard 910-78, "Standard for Solar Collectors," Air-Conditioning and Refrigeration Institute, Arlington, Virginia, 1978.

ASHRAE Standard 93-77, "Methods of Testing to Determine the Thermal Performance of Solar Collectors," American Society of Heating, Refrigerating and Air-Conditioning Engineers, New York, 1977.

ASHRAE Standard 94-77, "Methods of Testing Thermal Storage Devices Based on Thermal Performance," American Society of Heating, Refrigerating and Air-Conditioning Engjneers, New York, 1977.

Berkowitz, J.B. and R.A. Horne, Solar Enerzy-II: The Potential for the Solar Heating and Cooling of Buildings, Arthur D. Little, Inc, Cambridge, Massachusetts 1976.

Building the American City, Report of the National Commission in Urban Problems to the Congress and to the President of the United States, The Douglass Connission 1968.

Butt, Sheldon, "News from SELA--Update on Collector Tests and Standards," Solar Engineering, May 1978.

"Consumer Tax Credit Label Underway," Sun Up, November 1978.

DeAngelis, Michael, "The Challenge of Establishing Eligibility Guidelines for the California Solar Energy Tax Credit," Proceedings of the 1978 Annual Meeting of the American Section of the International Solar Energy Society, Ins., Vol. 2.2, 1978.

Energy Research and Development Adninistration, Barriers Connected with Certifying or Listing of Energy Conserving Products Used in Buildings, prepared by Hittman Associates, Inc., May 1977.

Fenves, Steven J., et al., The Structure of Building Specifications, National Bureau of Standards, NTIS $\overline{P B 257581}$, September 1976. 
Field, Charles G. and Steven R. Rivkin, The Building Code Burden, Lexington Books, Lexington, Massachusetts, 1975.

Florida Solar Energy Center, Solar Energy Commercialization at the State Level" The Florida Solar Energy Water Heater Program, prepared for FEA and the State of Elorida, FSEC 76-3, March 1977. Fox, Joel, "Solar Collector Testing," Sun Up, November 1978.

Fox, Joel, "Solar Collector Testing," Sun Up, November 1978.

Hemenway, David, Industrywide Voluntary Product Standards, Bellinger Publishing Company, Cambridge, Massachusetts, 1975.

Holton, John K., "Updating Solar Performance Criteria and Standards," Proceedings of the 1978 Meeting of the American Section of the Illecuallonal Solar Energy society, Inc., Vol. 2.1, 1978.

"Interitn Performance Criteria for Commercial Solar Heating and Combined Heating/Cooling Systems and Facilities," Document No. 98M1001, George C. Marshall Space Flight Center, Huntsville, Alabama, February 1975.

"Interim Performance Criteria for Solar Heating and Combined Heating/Cooling Systems and Dwellings," National Bureau of Standards, Washington, D.C., January 1, 1975.

"Interim Performance Criteria for Solar Heating and Cooling Systems in Commercial Buildings," NBSIR 76-1187, National Bureau of Standards, Washington, D.C., November 1976.

"Intermediate Minimum Property Standards for Solar Heating and Domestic Hot Water Systems," NBSIR 77-126, National Bureau of Standards, Washington, D.C. 20234, March 1977.

"Intermediate Standards for Solar Domestic Hot Water Systems/HUD Initiative," NBSIR 77-1272, National Bureau of Standards, Washington, D.C. 20234, Ju1y 1977.

Jordan, Richard and Benjamin Liu, eds. Application of Solar Energy for Heating and Cooling of Buildings, ASHRAE, New York City, New York, 1977.

Meeker, Frank 0., III, Building Codes as Barriers to Solar Heating and Cooling of Buildings, Environinental Law Institute, Washington, D.C., Apri1 1978.

Meyer, Don, "Standards for Wind Systems," AWEA Newsletter, February 1978.

Miller, A.S. and G.P. Thomas, Legal Barriers to Solar Heating and Cooling of Buildings, Environmental Law Institute, Prepared for DOE, March 1977.

Newton, Alwin B., "Certifying Solar Equipment," Solar Age, December 1978.

Newton, Alwin B., "Getting the Most Out of ASHRAE 93-77," Solar Age, November 1978. 
Oddo, Sandra, "Standards and Codes," Solar Age, May 1978.

Plan for the Development and Implementation of Standards for Solar Heating and Cooling Applications: NBSIR 78-1143A, prepared by the National Bureau of Standards, The Office for Conservation and Solar Applications, DOE, Washington, D.C., 1978.

The President's Committee on Urban Housing (The Kaiser Committee), A Decent Home, Washington, D.C.: U.S. Government Printing Office, $0 \overline{3} 1 \overline{3-957}$, $\overline{1969 .}$

Reyneveld, Joshua, "The California Testing and Inspection Program for Solar Equipment," Proceedings of the 1978 Meeting of the American Section of the Internationa1 Solar Energy Society, Inc., Vol. 2.2, 1978.

Sanderson, Richard, Codes and Code Administration: An Introduction to Building Regulations in the United States; Building Officials Conference of America, Inc., Chicago, 1 969.

Schoen, Richard; Alan S. Hirshberg and Jerome M. Weingard, New Energy Technologies for Buildings, Ballinger Publishing Co., Cambridge, $1 \overline{975 .}$

Solar Engineering, "National Certification: Where are the Standards?" February 1978 .

Solar Outlook, "Solar Standards--What's In a Label?" November 1977.

Tennyson, George, "Test and Product Standards for WECS," AWEA Newsletter, Summer 1977.

Uniform Solar Energy Code, International Association of Plumbing and Mechanical Officials, Los Angeles, California, 1976.

Underwriters Laboratories, Inc., Methods of Development, Revision, Implementation, Standards for Safety, Northbrook, Illinois, $197 \overline{5 .}$

Underwriters Laboratnries, Tnc., Testing for Public Safety, Northbrook, Illinois, 1976.

U.S. Congress, Senate, Committee on the Judiciary, Voluntary Industrial Standards, Hearings before a subcommittee of the Senate Committee on the Judiciary on S.3555, 94th Congress, 2nd session, 1976.

U.S. Congress, Senate, Committee on the Judiciary, Voluntary Industrial Standards, Hearings before a subcommittee of the Senate Committee on the Judiciary, 93rd Congress, lst Session, 1975. 
THIS PAGE INTENTIONALLY LEFT BLANK 


\section{APPENDIX A \\ STANDARDS AND CODES \\ GOVERNMENT STATUTES, REGULATIONS, AND GUIDELINES}

\section{Federal}

The Solar Heating and Cooling Demonstrations Act of 1974 (PL 93-409), U.S. Code Annotated $\S \S 5501$ et. req.

\section{California}

Health and Safety Code $\$ 41261$.

Public Resources Code $\S \S 25600-25609$.

Revenue and Taxation Code $\S \S 17052.5$ and 23601 .

Tax Credit Guidelines and Criteria, California Administrative Regulation $\$ \S$ 2601-2608.

California Energy Commission, "Standards and Procedures: Accreditation of Testing Laboratories for Solar Components and Systems," May 31, 1978.

California Energy Commission, "Guideline for Certification of Solar Energy Equipment," June 15, 1978.

\section{Florida}

Florida Statutes Annotated $\S 377.705$

Florida Solar Energy Center, "Test Methods and Minimum Standards for Solar Collectors," FSEC 77-5, November 1977.

Florida Solar Energy Center, "Operation of the Collector Certification Program," FSEC 77-6, November 1977.

Florida Solar Energy Center, "Solar Energy Commercialization at the State Level: The Florida Solar Energy Water Heater Program," FSEC 76-3, March 1977.

\section{Minnesota}

Minnesota Statues Annotated $\S 116 \mathrm{H} .127$. 
Minnesota Code of Agency Rules $\$ \S 1.16101-1.16108$, "Standards of Performance for Solar Encrgy Systems and Subsystems Applied to Energy Needs of Buildings," 1977.

Oregon

Oregon Revised Statutes $\S 307.175$.

Oregon Revised Statues $\$ \S 469.160-469.180$.

Oregon Revised Statutes $\$ 407.048$.

Oregon Administrative Rules $\$ 274-20-345$ and $330-80-010$ through $330-80-080$. 


\section{APPENDIX B}

\section{INDIVIDUALS INTERVIEWED}

\section{California}

Michael DeAngelis, Solar Energy Specialist, California Energy Commission (July $11,1978)$.

Richard Piersen, Solar Energy Specialist, California Energy Commission (July $10,1978)$.

Joshua Reyneveld, Solar Energy Specialist, California Energy Commission (July $10,1978)$.

Gregg Wheatland, Legal Counsel, California Energy Commission (July 10, 1978).

\section{Florida}

James Huggins, Assistant Manager of Testing and Certification Program, Florida Solar Energy Center (September 21, 1978).

James Roland, Manager of Testing and Certification Program, Florida Solar Energy Center (September 21, 1978).

\section{Minnesota}

Ned Hoffman, Science Museum of Minnesota, Ouroboros Project (August 4, 1978).

Sam Rankin, Legislative Analyst, House of Representatives Research Dept., Minnesota State Legislature (August 3, 1978).

Ron Rich, Director of Solar Energy Office, Minnesota Energy Agency (August 3, 1978).

Dary1 Thayer, President, Dary1 Thayer Associates (August 3, 1978).

Karen Wilson, Minnesota Energy Alternatives Lobby (August 3, 1978).

\section{Oregon}

Norm Clark, Assistant Construction Analyst, Department of Veterans' Affairs (.July 12,1978 ).

C.J. Hill, Liaison Assistant, Department of Revenue (Ju1y 20, 1978).

Alan D. Kiphut, Solar Specialist, Department of Energy (July 20, 1978). 
No. of Copies

1

1

1

1

1

1

1

1

1

1
Distribution

Department of Energy: DOE, SERI Site Office

Contracting officer

Attn: Charles M. Skinner

Chicago Operations office Interim Program Division

Attn: M. E. Jackson

Division of Solar Technology Office of Asst. Director

for Administration

Attn: R. H. Annan

Office of Asst. Secretary for Conservation \& Solar Applications

Attn: R. Scott

Office of Solar, Geothermal, Electric \& Storage Programs

Attn: Martin Adams

Division of Energy Technology Administration

Attn: S. Hansen

Division of Distributed

Solar Technology

Office of the Director

Attn: R. San Martin

Division of Central Solar

Technology

office of the Director

Attn: H. Coleman

Division of Energy Storage

Systems, ETS

Office of the Director

Attn: G. Pezdirtz

Division of Planning \& Energy Transfer, ETS

Office of the Director

Attn: Leslie Levine

Wind Energy Systems

Attn: L. Divone 